\title{
Memória, Imagem e Som em Trois couleurs: Bleu, de Kieślowski
}

\section{Gabriela Santos Alves}

Doutora em Comunicação e Cultura, depto. de Comunicação Social, UFES - Brasil. E-mail:

gabrielaalves@terra.com.br

\section{Marcus Vinicius Marvila das Neves}

Mestre em Estudos Literários, depto. de Teoria da Arte e Música, UFES - Brasil. E-mail: creed.mvmn@gmail.com
Resumo: primeiro filme da trilogia de Krzysztof Kieślowski dedicada às cores e aos ideais da Revolução Francesa, Trois couleurs: Bleu tem como questão central a discussão acerca da liberdade: é possível alcançá-la em toda sua plenitude? Ou, ainda: é possível viver sem manter vínculos? Julie, personagem central, assume o anonimato em meio a multidão parisiense após um trágico acidente em que morrem seu marido e filha, afastando-se de tudo e todos na tentativa de livrar-se do passado e esquecer a tragédia. "Não quero bens, presentes, amigos, amor e vínculos. Tudo isso são armadilhas", afirma. A análise da obra se baseia na relação memória e esquecimento que Kieślowski propõe a partir de uma complexa trama entre som e imagem, onde os elementos-memória constroem polifonicamente os intempestivos deslocamentos tempo-espaciais e o drama silencioso vivido pela personagem de Juliette Binoche.

Palavras-chave: Trois couleurs: Blue; memória; silêncio; som; imagem.

Title: Memory, Image and Sound in Trois couleurs: Bleu, by Kieślowski

Abstract: The first film in the Krzysztof Kieślowski trilogy dedicated to colors and to the ideals of the French Revolution, Trois couleurs: Bleu is a central issue the discussion about freedom: it is possible to achieve it in all its fullness? Or: can we live without maintaining links? Julie, the central character, assumes anonymity amid the parisian crowd after a tragic accident that killed her husband and daughter, away from everyone and everything in an attempt to get rid of the past and forget the tragedy. "I do not want goods, gifts, friends, love and relationships. These are all traps" she says. The analysis of the work is based on the relationship memory and forgetting that proposes Kieślowski from a complex interplay between sound and image, where the elements-memory construct polyphonically the untimely time-space displacement and the silent drama experienced by the character of Juliette Binoche.

Keywords: Trois couleurs: Bleu; silence; audio; image.

Penso neles, meu Deus! Eu me lembro de tudo. Como esquecer? (TRILOGIA..., Cap.2)

Trois couleurs: Bleu (1993), do diretor polonês Krzysztof Kieślowski, é um filme que fala de dor, trauma, perdas e, especialmente, de memória e música. Falar talvez não seja o verbo mais apropriado, já que a proposta de Kieślowski na direção de seus filmes é justamente sugerir, apontar pistas para os acasos, para a cadeia 
de casualidades que envolve o cotidiano de seus personagens e onde os efeitos não são palpáveis, não estão presentes. Cineasta das coincidências, solicita do espectador um permanente estado de escuta e de visão.

Em Bleu, a personagem central da trama, interpretada por Juliette Binoche, perde a filha e o marido, Patrice, num trágico acidente de carro e opta, então, por viver num bairro central de Paris, sozinha e em completo anonimato, sem vínculos com o passado. "Não quero bens, presentes, amor, amigos ou vínculos. Tudo isso são armadilhas" (TRILOGIA... , Cap. 7), afirma Julie à mãe que, internada numa clínica para idosos, sofre com problemas de memória. Trois couleurs: Bleu integra, ao lado de Trois couleurs: Blanc (1994) e Trois couleurs: Rouge (1994), a Trilogia das Cores, projeto surgido em 1989 com o objetivo de refletir, partindo de parâmetros da atualidade, sobre o significado dos ideais da Revolução Francesa no ano da comemoração de seus 200 anos, não somente pela alusão às cores da bandeira do país, como também pela formação, à época ainda em fase inicial, com 12 países, da União Europeia:

A nova situação da Europa (e da própria América Latina) gera "maneiras de estar" no mundo, e o Kieślowski da trilogia é um cineasta que pensa este momento singular da história ocidental. As contradições atuais da Europa (terrorismo, migração, miséria), seus questionamentos pessoais (o significado da derrocada do regime comunista na Polônia, o duro golpe militar, a instalação de sítio, a religião católica) e seu estatuto de cidadão europeu apontam para um Kieślowski desiludido e realista (FRANÇA, 1996: 17).

É importante ressaltar que a tradução brasileira dos títulos não mantém seus nomes originais, já que os denomina de $A$ liberdade é azul, A igualdade é branca e $A$ fraternidade é vermelha, vinculando a cada um, especificamente, o ideal em questão e antecipando a interpretação do espectador. A proposta de Kieślowski transgride essa ideia, já que reflete sobre os três ideais nos três filmes, mesmo que em abordagens e intensidades distintas: "as três noções são contraditórias como a natureza humana... se as tocamos, não sabemos muito bem o que fazer e como viver com elas" (CIMENT, 1993: 20).

A filmografia de Kieślowski, que teve início na Polônia em fins da década de 1960, contempla a produção de curtas e longas metragens. Marcada pela realização de documentários, a fase inicial aborda temas como o cotidiano das cidades polonesas, burocracia governamental, funerais, soldados que ficaram cegos na Segunda Guerra Mundial, condições de trabalho, greves, doenças, gravidez indesejada e corrupção. Ao tratar de eventos cotidianos, o diretor privilegia questões que ultrapassam fronteiras culturais, estando essa marca também presente em sua produção de longas de ficção. Em 1988, filma Decálogo (Le Décalogue), série para a televisão polonesa que consistia em dez médias metragens baseados nos Dez Mandamentos.

Após filmar o Decálogo, Kieślowski iniciou a chamada "fase ocidental" de sua produção, quando gravou A dupla vida de Véronique (La double vie de Véronique, 1991) e a Trilogia das Cores, com recursos financeiros do governo francês. Nessas obras, o cotidiano ainda é cenário e a abordagem direta e geral dos temas tratados nos documentários dá lugar a um mergulho na subjetividade humana e nos detalhes da vida, geralmente negligenciados:

Percebi quantas facetas da vida um documentário não pode abordar (...). Ultimamente, me parece que eu faço filmes sobre os pensamentos e emoções mais profundos das pessoas, aquilo que elas não mostram a ninguém. Para filmar isso preciso de atores, de lágrimas de glicerina, de cenas de morte. Tudo tem de ser falso para parecer real no filme. Graças a essas coisas falsas, posso dar um sopro de vida à história. Tudo é mais interessante na vida real, mas nunca deve ser filmado na vida real. Por isso não faço mais documentários (100 Questões..., 1989). 

${ }^{1}$ Aqui, a expressão trilha sonora será
usada para se referir às músicas, sound
effects, foley, diálogos e ambiências
presentes na película. Teremos como
foco principal as inserções musicais e
sequências em que o som aparece como
elemento fundamental para a narrativa.
Esse último período de produção marca uma postura mais audaciosa do diretor quanto ao uso da trilha sonora como ferramenta narratológica ${ }^{1}$. Nesses casos se constrói o supercampo, denominação dada por Chion (2011: 119) à ampliação da experiência sensorial do espectador a partir do uso de sistema sonoro multicanal, potencializando o poder narratológico do som, logo, retirando da imagem, do plano geral, a obrigatoriedade narrativa. Chion, discursando sobre a música em Bleu, aponta: "Kieślowski foi um entre os raros autores-diretores que souberam tirar o melhor proveito do Dolby Stereo e do meios para contrastar e opor espaços e volumes dentro da música no cinema" (1997: 276, tradução nossa).

Depois de trabalhar com quatorze engenheiros de som em $A$ Dupla vida de Véronique, para a trilogia, em acordo com seu novo produtor Marin Karmitz, Kieślowski observou a necessidade de um único engenheiro de som que trabalhasse na captação, montagem e mixagem até a cópia final dos três filmes, dada a importância da música e do som nas narrativas. Contratou-se Jean-Claude Laureux, que exerceu notória influência na concepção sonora dos filmes, conforme aponta o próprio diretor (STOK, 1994: 220-221) e Karmitz (TRILOGIA..., Disco 3, Extras).

Assim, formou-se a trinca sonora, Kieślowski, Laureux e Zbigniew Preisner. Este último, compositor, construiu profícua parceria com o diretor, seu compatriota, tendo realizado trilha sonora original para 17 de suas películas, todas a partir de 1984, começando por Sem Fim (Sans Fin), à exceção apenas de Sorte Cega (Le Hasard), de 1987. Sobre Preisner, o próprio diretor aponta o lugar do compositor no processo de produção musical para seus filmes:

\begin{abstract}
Eu não sei nada sobre música. Eu sei mais sobre a atmosfera do que a música em si. Eu sei que tipo de atmosfera quero ter em meus filmes mas não sei qual música iria me ajudar a alcançar isso nem como escrever essa música. Zbyszek Preisner é alguém com quem eu posso trabalhar em equipe, em vez de apenas pedir a ele um determinado efeito, já composto. Muitas vezes eu quero colocar música onde ele acredita que soaria absurdo, e há cenas que eu não imagino ter música, mas que ele acha que deve ter, então vamos colocar música ali. Ele é definitivamente mais sensível nesta área do que eu. Eu penso de uma forma mais tradicional enquanto que seu pensamento é mais moderno, cheio de surpresas. É isso, me surpreende onde, no filme, ele quer música. (STOK, 1994:224; tradução nossa)
\end{abstract}

A manutenção de um diálogo aberto com Preisner ea preocupação com o uso do som como elemento narrativo, chegando à figura de Jean-Claude Laureux, contribuem para que essa última fase do cinema de Kieślowski potencialize meticulosamente os planos sonoros ao ponto de guiarem, amplificarem e aprofundarem o significado de determinadas cenas. É a partir do estranhamento sonoro, da música e do som como temporalizador estrutural da imagem e do seu uso como contraponto às sombras projetadas na tela que Kieslowski opta por nos colocar "diante de uma realidade que no cotidiano não nos escapa expressar" (KICKASOLA, 2012: 72).

A potencialização meticulosa dos planos sonoros aliada à esfera do cotidiano como cenário - herança do período em que Kieślowski atuava como documentarista marcam a última fase de produção do diretor. Nessa linha, outras heranças da fase documentarista podem ser apontadas, especificamente, em Bleu. A "aparência de verdade" do apartamento em que Julie decide morar após abandonar a casa em que vivia com o marido e a filha, mortos no acidente: ele está localizado na Rue Mouffetard, distrito pouco turístico do centro da cidade e uma região tipicamente parisiense, com um café que dispõe suas mesas e cadeiras nas calçadas e está acessível logo após a saída de uma estação de metrô. Como assinala o próprio diretor, outro fator importante é a presença de um mercado de rua, lotado de transeuntes, marcando a ideia de que a personagem poderia facilmente se perder ali, garantindo seu anonimato (STOK, 1994). 
Outro legado refere-se às opções de enquadramento de câmera: o uso do close e do plano detalhe em várias sequências do filme. Logo de início, vemos de perto o problema no carro que levará ao acidente. Quando Julie está hospitalizada em função do acidente, uma pequena pluma branca movimenta-se sobre um lençol, em close, acompanhando o movimento da respiração da personagem, quando pode-se ouvir o frágil som do seu respirar, elementos que denunciam a existência de algum sobrevivente. Em seguida, ao entrar no quarto para verificar o estado de saúde dela, o médico é apresentado ao espectador pelo reflexo dele no olho de Julie, também em close. As perguntas feitas à paciente são respondidas pelo movimento de seu olho, para cima ou para baixo, sem mudança de enquadramento.
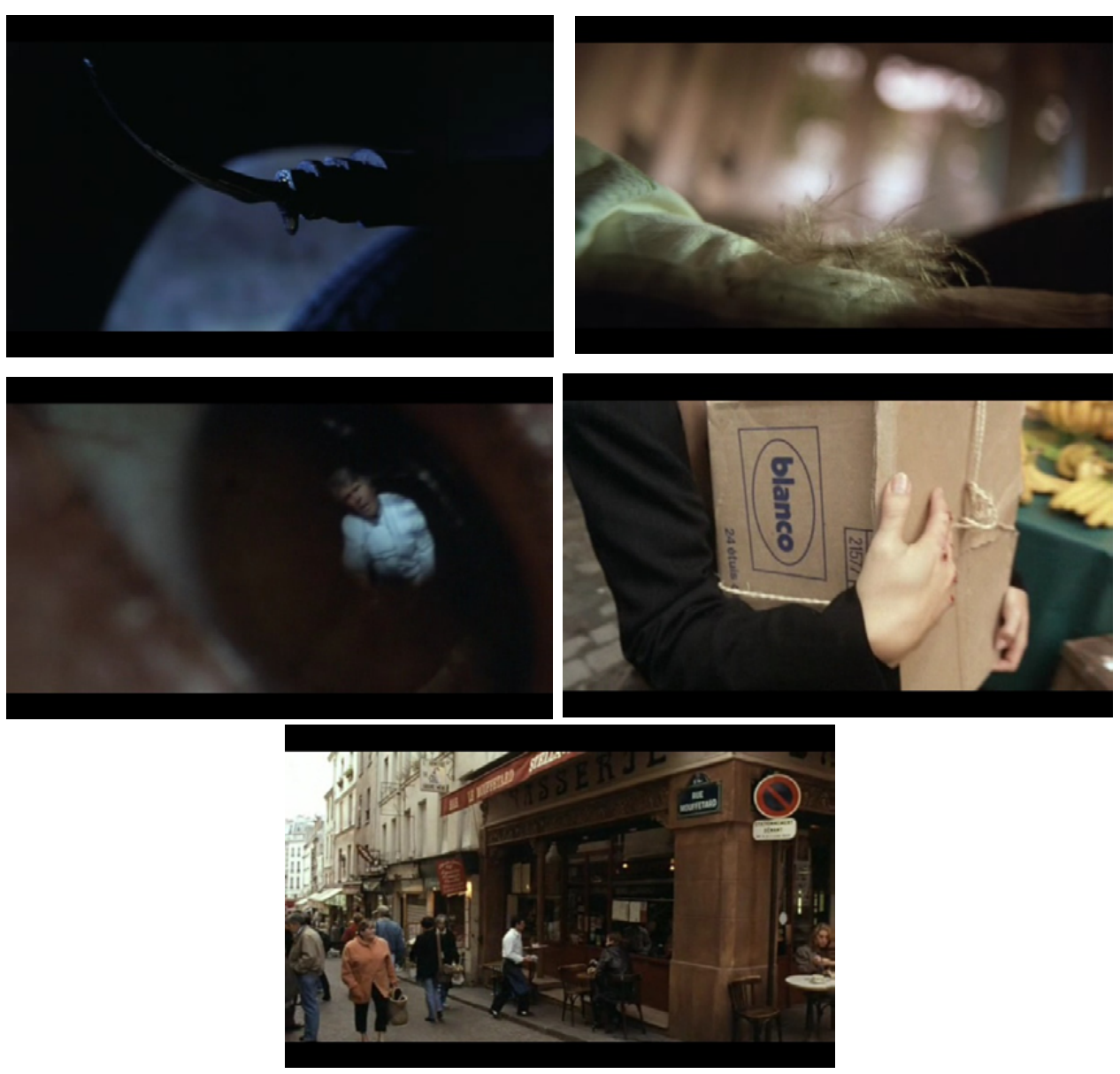

Da esquerda para direita: [1] o gotejar do carro; [2] a pluma; [3] o médico pelo olho; [4] Julie no mercado de rua, rapidamente podemos ver a referência ao branco, breve intertexto com Trois couleurs: Blanc; [5] Julie segue pela rua e vemos a placa no alto, à direita, apontando sua localização

Na tomada seguinte, Julie acompanha o enterro do marido e da filha através de um aparelho de tv portátil, numa sequência que demarca a primeira aparição de uma música no filme. Antes de falecer, o marido da personagem trabalhava na composição de uma peça intitulada "Concerto para a integração da Europa", que deveria ser executada em 12 cidades diferentes, por 12 orquestras distintas, em clara alusão ao processo de criação da União Europeia, ainda incipiente. Essa sequência guarda uma das forças centrais do trabalho do diretor polonês, quando sincronias e desencontros entre imagem e som proporcionam camadas contrapontísticas de alta complexidade.

${ }^{2}$ Todas as músicas serão citadas conforme aparecem nomeadas no cd oficial da trilha original do filme em questão.
A música que se ouve é a "Funeral Music"2, de Van den Budenmayer (1755-1803). Fictício compositor neerlandês do século XVIII, foi criado por Preisner e já havia sido citado/ouvido em filmes anteriores de Kieślowski, a exemplo do nono episódio do Decálogo e em A Dupla Vida de Véronique, além da importante função em Trois Couleur: Rouge. Mais tarde, Julie, em conversa com Olivier, revelaria ao espectador que Patrice tinha profunda admiração pela obra de Budenmayer e, ao longo do filme 
é possível, inclusive, percebemos a semelhança temática entre o concerto inacabado e a música do neerlandês executada no funeral. Ao mesmo tempo que vemos Julie acompanhar o velório do marido pela tv portátil, somos levados a duvidar, em uma escuta mais atenta, se "Funeral Music" está realmente sendo executada durante o funeral pela banda de instrumentos de sopro que nos é mostrada nessa montagem alternada ou se ali já adentramos à subjetiva escuta de Julie.

A música - que em suas pausas são rigorosamente preenchidas por elementos narrativos singulares: o som angustiante do hospital; as respirações de Julie e seu silêncio verbal; a aparição na tv da imagem de Olivier mostrando ao espectador seu grau de proximidade com o falecido compositor; o gesto de Julie de acariciar o caixão da filha - antecipa-se à sintonização da imagem da tv, não há relação sincrônica entre a imagem da respiração do trombonista, sobre a qual ouvimos a respiração de Julie, e a primeira nota da frase musical por vir que ouvimos junto ao corte para o rosto da personagem. Toda vez que somos levados a ver Julie escutamos a continuidade musical. A música também não coincide seu fim no áudio com o gesto da clarinetista e, muito para além da assincronia, temos ali uma pista já que "Funeral Music" de Budenmayer que ouvimos em cena não tem em sua formação instrumental o clarinete. São marcas sutis que nos permitem acessar o mundo das ambiguidades propostas pelo diretor polonês em sua filmografia.
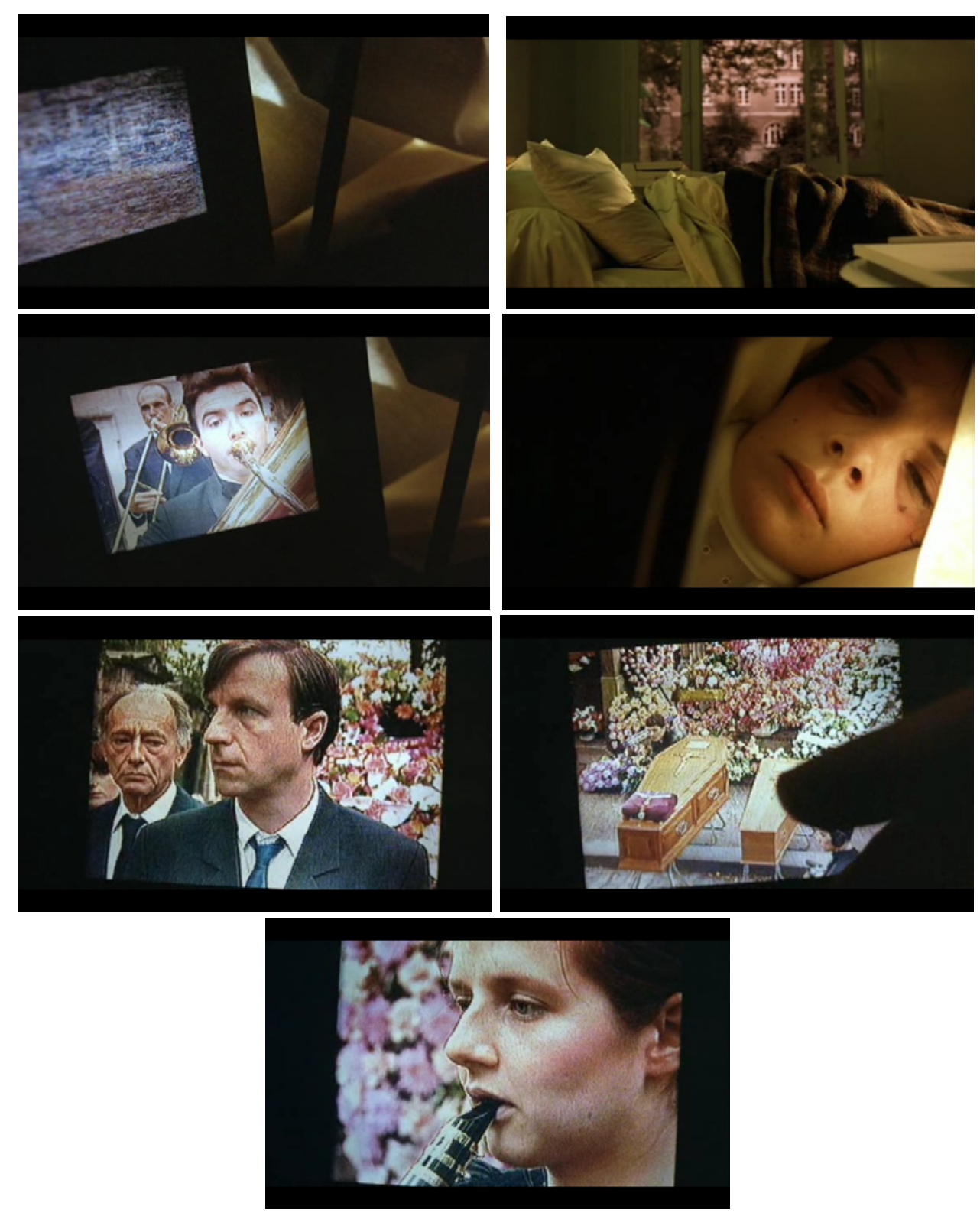

Da esquerda para direita: [1] enquanto a tv sintoniza já ouvimos claramente a música, mesmo que ela traga uma qualidade som de televisão em sua emissão; [2] Julie se cobre, temos a primeira pausa e ouvimos um glissando oriundo do som ambiente do hospital; 
[3] vemos o trombonista respirar, mas ouvimos o gesto respiratório de Julie, a música retoma "empurrando" o corte para o rosto da viúva; [4] nova pausa entre as frases musicais e vemos Olivier; [5] na outra pausa, o gesto de carícia de Julie; [6] quando vemos a clarinetista, já não ouvimos mais a música.

Durante todo o filme Kieślowski posiciona o espectador na escuta da personagem, diegética e ao mesmo tempo interna, conforme aponta Chion (1997: 275). A música se dá quase em sua totalidade, no que se refere à Julie, na sua mente, seja pela memória que busca o som da flauta do músico de rua, seja pelo solfejo relativo à uma música grafada em partitura que, por sua vez, é um documento musical que guarda em si uma sonoridade passada só passível de ser ouvida quando ativada e presentificada mediante o ato de entoar, mesmo que mentalmente, o som. Bleu, como afirmamos no início do texto, é um filme que trata de memória e de música. Nesse sentido, Chion afirma:

O roteiro gira em torno do nascimento, do renascimento da vida, de sons perdidos, não realizados, enterrados na memória da esposa e em folhas de papel pautado. Trata da fragilidade da música e da fragilidade da mensagem artística em geral, verdadeira garrafa jogada ao mar, de sua circulação e também sua capacidade de passar de humano a humano, de pertencer a todos, ao mesmo tempo que é a expressão de um indivíduo. (1997:275)

É também sobre igualdade, fraternidade e, acima de tudo, sobre liberdade, ou sobre as imperfeições da liberdade humana: qual o sentido da liberdade? Está Julie, após perder o marido e a filha, completamente livre? Com dinheiro suficiente para se manter e sem obrigações a cumprir, ela decide viver uma vida diferente, tentando se libertar de tudo que está ligado ao seu passado. Ainda no hospital, ao cuspir os remédios que havia ingerido certamente para esse fim, a personagem deixa clara sua opção pelo não suicídio - por razões que o espectador nunca saberá.

O desejo de se libertar desse passado evidencia-se justamente nas não atitudes da personagem: Julie, em momento algum da narrativa, aparece visitando os túmulos em um cemitério, chorando a perda dos entes queridos publicamente ou observando fotos antigas, ações comuns para quem tornou-se viúva recentemente e perdeu uma filha. Ao contrário, somos apresentados às fotos antigas da família quando Olivier, compositor amigo do finado marido de Julie e com quem ela se envolverá sexualmente durante o desenrolar da narrativa, abre a pasta azul dentro de seu carro ao sair da casa de viúva, pasta que seria compilada com os papeis retirados de dentro das gavetas de uma suposta mesa de trabalho de Patrice, em uma cena curtíssima, precedida do assédio da jornalista a Julie ainda no hospital. Assim que Julie sai do hospital e decide abrir mão de tudo, é questionada por Marie, empregada que cuida da antiga casa: "por que você não chora?" (TRILOGIA... , Cap. 2).

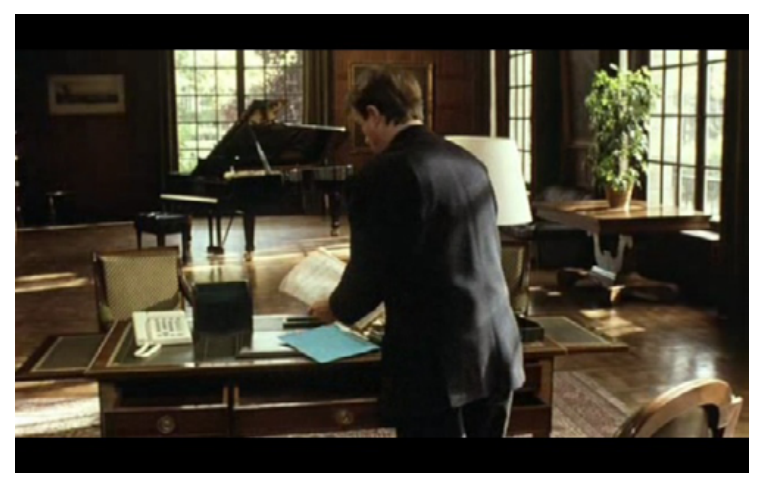

Olivier recolhe os papeis e os coloca dentro da pasta azul, ao fundo vemos o piano aberto, nos remetendo a ideia de que ele se encontra na sala da casa de Patrice após o acidente, enquanto isso é possível ouvir bem ao fundo, de perfil não-diegético o som de uma voz que faz aquecimentos vocais, instrumentos acústicos fazendo escalas, uma confusão sonora simulando as próprias partituras espalhas pelo móvel sendo recolhidas por Olivier na pasta sem qualquer ordem. 


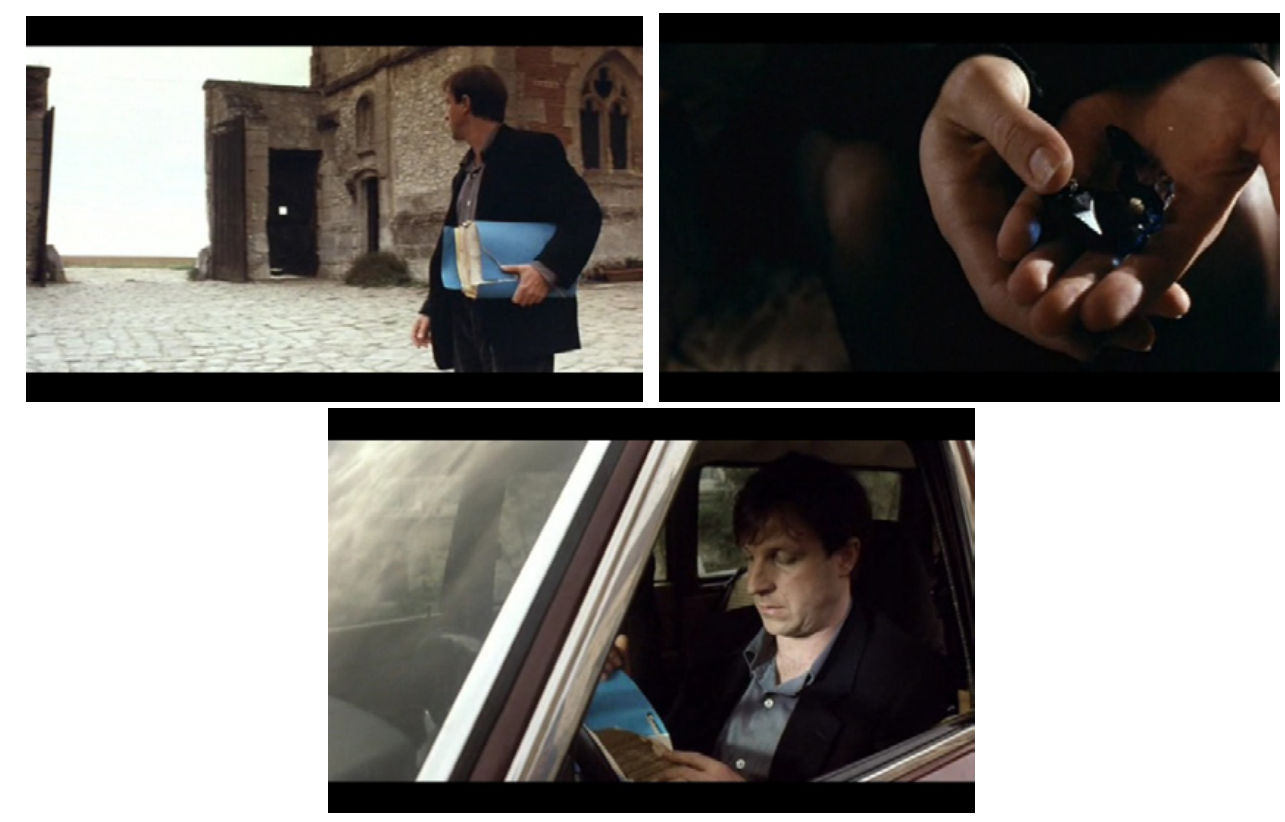

[1] Olivier sai da casa de Patrice e Julie com a pasta e se assusta, pois ouve tiros que não sabemos de onde partem; [2] enquanto isso, em nova sequência de montagem alternada Julie está conversando com seu advogado sobre a venda de seus bens, temos um close em suas mãos segurando as pedras azuis que compõem o lustre, a fundo continuamos ouvindo os tiros (entes acústicos) que demarcam a simultaneidade das ações de Julie e Olivier; [3] o compositor adentra o carro, abre a pasta e localiza as fotos da família que denunciam o caso extra-conjugal, ao fundo os sons de tiros continuam: seria uma metáfora do esfacelamento familiar?

Ao decidir libertar-se de seu passado, a personagem passa a viver no apartamento localizado na Rue Mouffetard e, em meio às atividades rotineiras que cumpre, como ir ao supermercado, nadar ou almoçar no restaurante mais próximo, percebe que a ideia de liberdade sem vínculos é ilusória e que o passado está com ela, vivo e presente, seja no lustre azul que trouxe de recordação do quarto da filha - único objeto da antiga casa, por sinal - ou na música que insiste em revelar-se, trazendo a tona uma mescla entre a lembrança do tema musical escrito pelo marido e uma continuidade composicional da própria Julie que é aflorada nesses espasmos musicais.

A memória, em Bleu, não está ligada a imagens de uma memória psicológica, quando lembranças de um fato qualquer são evocadas por um personagem, e nem a uma memória coletiva, em que evoca-se experiências passadas e comuns para um determinado povo, como o europeu, por exemplo. No filme, assim como em toda a trilogia, a memória constrói-se a partir do particular, traduzido pelas trajetórias individuais de cada personagem - como Julie - aliado ao universal como o ideal de liberdade ou a universalidade da arte. Entrelaçados, permitem construir um tema narrativo, a exemplo do paradoxo entre a personagem e sua mãe: enquanto a primeira não quer fixar seu passado e nem lembrar-se dele, apesar de estar vivo dentro dela, a segunda fixa, por meio das fotografias que exibe nos porta-retratos de seu quarto, um passado que já não reconhece mais.

Esse passado vivo, que tanto atormenta Julie e se presentifica via música é, para Bergson (1990), um elemento ontológico do tempo, que existe junto ao presente, de maneira simultânea, ainda que não se confunda com o presente atual. Nessa linha, o passado não é cronológico, não é algo que foi e nem é presente que passa ou que foi empurrado para trás. O passado é, ele preexiste com o uma espécie de memória-Mundo ou memória-Ser. A memória, assim, não existe em nós, mas somos nós quem pertencemos e nos movemos numa memória do mundo, onde o presente é o grau mais contraído desse passado: 
Mas como o passado, que, por hipótese, cessou de ser, poderia por si mesmo conservar-se? Não existe ali uma contradição verdadeira? Respondemos que a questão é precisamente saber se o passado deixou de existir, ou se ele simplesmente deixou de ser útil... (BERGSON, 1990: 123).

Esse passado, ou lembrança pura, contém infinitos virtuais que não necessariamente se atualizam no agora, já que existem vários virtuais que nos habitam e que, devido a um presente que mobiliza deste passado apenas o que the interessa para a ação imediata, estão impedidos de se atualizarem. As lembranças vão, pouco a pouco, aparecendo como que uma nebulosidade que se condensa, passando do estado virtual para o atual, à medida que seus contornos se desenham. Mas continuam, por outro lado, presas ao passado por raízes profundas e, quando realizadas, ressentem-se de sua virtualidade original, caso contrário, não seriam jamais reconhecidas como lembranças (Ibdem, 156).

O passado vivo, que pulsa e presentifica-se, é evidenciado em Bleu pelos vários objetos e ações dos personagens marcados pela cor azul: o papel de bala com que a filha brinca no carro na primeira sequência do filme (e que posteriormente Julie encontrará um idêntico em sua bolsa), a pasta com fotos familiares e documentos, o lustre, a água da piscina em que a personagem mergulha com frequência, como se buscasse, num gesto metafórico, um mergulho em si mesma:

É no azul que se encontra essa profundidade e, de maneira teórica, já em seu movimento: 1 ㅇ - movimento de distanciamento do homem; 2o - movimento dirigido para o seu próprio centro. O mesmo ocorre quando se deixa o azul (a forma geométrica é, neste caso, indiferente) agir sobre a alma. A tendência do azul para o aprofundamento torna-o precisamente mais intenso nos tons mais profundos e acentua sua ação interior. $\mathrm{O}$ azul profundo atrai o homem para o infinito, desperta nele o desejo de pureza e uma sede de sobrenatural. É a cor do céu tal como se nos apresenta desde o instante em que ouvimos a palavra "céu". O azul é a cor tipicamente celeste. Ela apazigua e acalma ao se aprofundar. (KANDINSKY, 1990: 86)
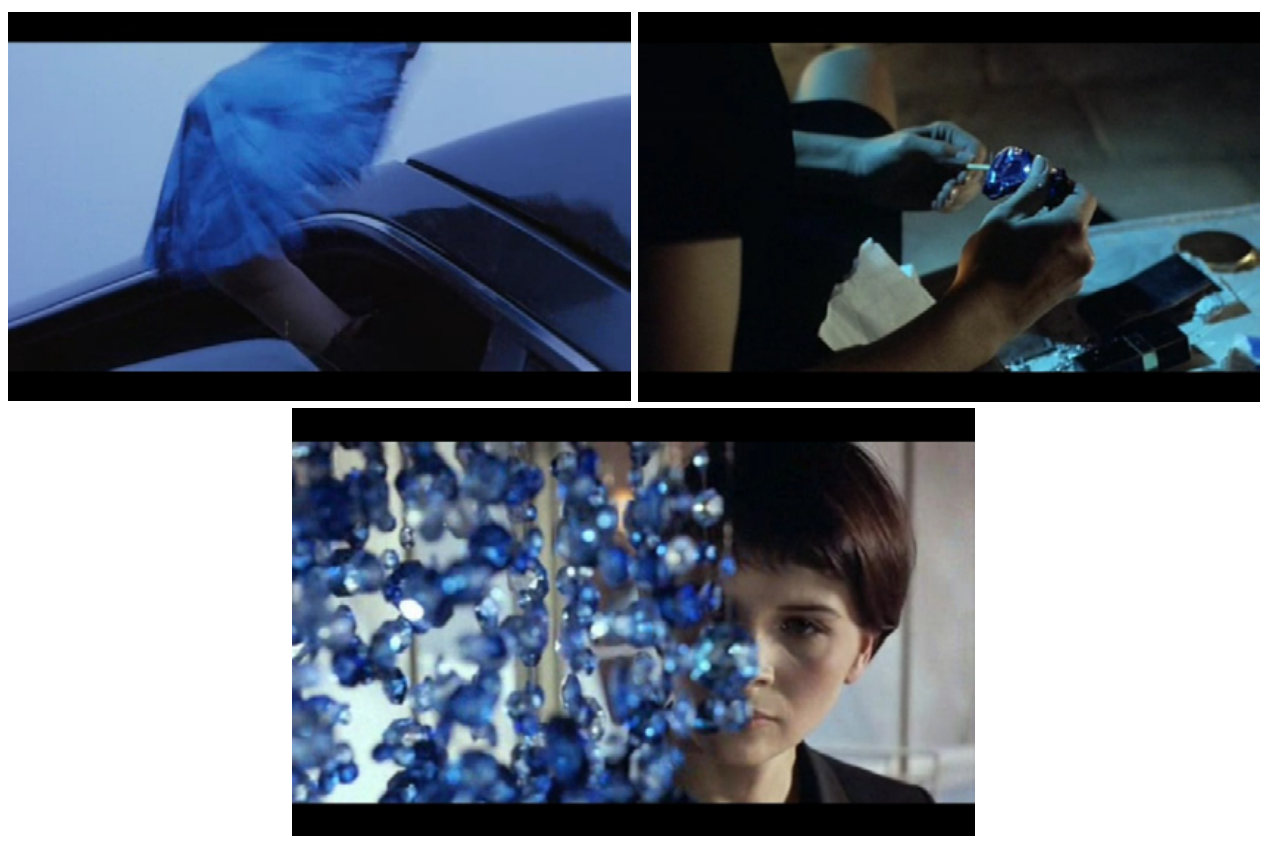

[1] Na sequência de abertura vemos o papel de bala; [2] Depois Julie acha em sua bolsa o pirulito que sobrou de sua filha; [3] o lustre é objeto-memória recorrente na narrativa.

O lustre e a música - e mesmo alguns sons recorrentes na película - são os grandes representantes do que chamamos de elementos-memória, que podem ser desde objetos, pessoas, animais, assim como efeitos imagéticos (ex: fade out) e sonoros (ex: reverb) e são utilizados pelo diretor não só para potencializar e pluralizar as linhas narratológicas, como para exigir do espectador que ele dialogue com as películas 
através da sua própria memória, seja ela através da sua experiência no cinema autoral de Kieślowski, ou mesmo através da vivência cotidiana que cada um levará para o confronto com os filmes. Tornada visível na narrativa através das partituras, a música se presentifica para a personagem, em especial, nos momentos em que ela está na piscina, além das passagens em que o recurso do fade out é utilizado. Clarificada pelo azul profundo muito próximo da perquirição de Kandinsky sobre a cor em seu primeiro livro teórico sobre arte (2000), a água onde Julie mergulha é um exemplo do trabalho da direção de fotografia de Slawomir Idziak que, ao optar pela utilização de poucos efeitos, aposta no uso da cor para transmitir o estado de espírito, o extremado ponto de vista da personagem.

O discurso sonoro criado por Laureux possui diversos entes acústicos que corroboram para a lista desses elementos-memória. Para Ángel Rodríguez, o ente acústico no audiovisual é "qualquer forma sonora que, tendo sido separada da fonte original de sua fonte original, é reconhecida pelo receptor como uma fonte sonora concreta situada em algum lugar de um espaço sonoro" (2006:57) e está sempre acusmatizado. É nesse jogo entre o acusmático e o imagético que a fonte sonora é colocada em questão durante todo filme em direção a uma narratologia própria do som. Um exemplo que pode passar sem maior importância é a presença do elemento cachorro que [a] passa correndo, assustado e latindo entre a terceira e a quarta batida da lataria do carro no acidente; [b] late, acusmatizado, cumprindo essa função de ente acústico, anunciando a chegada de Julie à sua casa após sair do hospital; [c] late novamente denunciando a chegada de Olivier enquanto Julie está sentada na escada, em uma sequência com destaque para a escolha com uma montagem paralela entre som e imagem em que cada um apresenta seu potencial narrativo; [d] passa acompanhado do dono e late ao lado da recorrente senhora que leva sua garrafa à lixeira. A figura do cachorro, aparentemente dispensável, acaba por compor uma complexa rede narrativa, já que o animal volta a assumir essa função anunciativa/denunciativa em Trois Coleurs: Blanc (1994) enquanto ente acústico até se tornar personagem chave em Trois Coleurs: Rouge (1994). Este é apenas um exemplo dentre vários outros elementos-memória que circulam pela Trilogia das Cores e vão se re-atualizando de acordo com a necessidade das narrativas e permitindo ao espectador ativar suas lembranças do contato com a filmografia de Kieślowski.
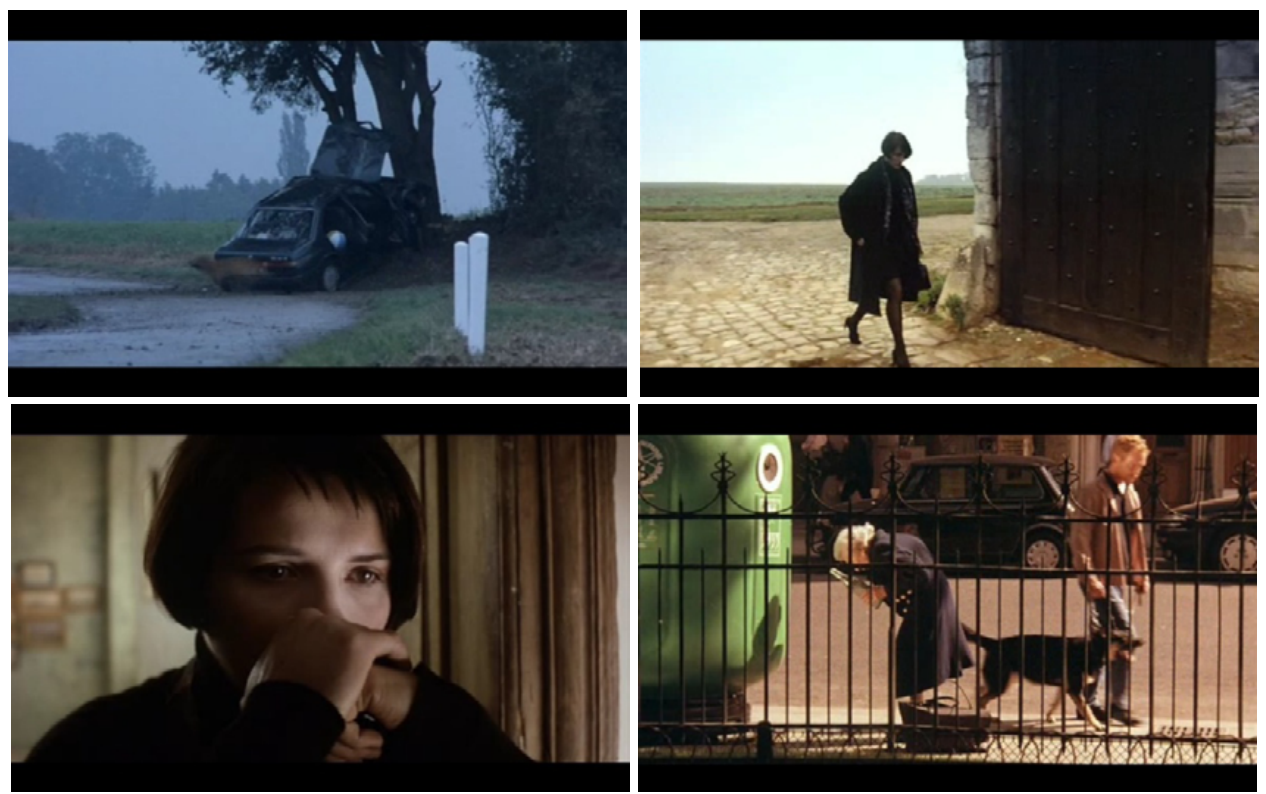

Da esquerda para direita: [1] o cachorro passa correndo durante a batida do carro; [2] Julie chega em casa, ouvimos o latir; [3] em outra sequência em que temos ações distintas entre som e imagem, acompanhamos pela escuta a chegada de alguém, depois descobrimos ser Olivier, anunciada pelo latido do cachorro e o som do carro; [4] na cena da senhora levando sua garrafa à lixeira, figura recorrente na filmografia de Kieślowski, um cachorro e seu dono passam pela senhora, ele late, chamando atenção 
do espectador, enquanto isso, Julie está em seu gozo escutando internamente a música do flautista e vemos fades out em branco (utilizados posteriormente apenas no gozo de Dominique com o "falecido" Karol Karol em Trois Coulers: Blanc).

A terceira aparição de Julie na piscina acontece após ser questionada por Lucille, "- está chorando?", seguida de fade out e da música "Julie glimpses of burial", na qual o instrumento solo, um oboé, tem seu discurso musical interrompido em sua metade, temos um fade in de retorno ao semblante de Julie, que desconversa. A viúva comenta e lamenta ter proporcionado, com ajuda do gato do vizinho, a morte dos ratos e seus filhotes. A sequência é interrompida novamente quando várias crianças chegam correndo e pulando na piscina. Se aqui, as imagens/sons das crianças se fazem presentes, ainda no começo do filme, enquanto Julie está no escritório da copista, principalmente quando observa as partituras das músicas de Patrice na estante, durante toda essa sequência temos ao fundo o som de crianças, como ente acústico de corpos que não se fazem presentes, mas que são reconhecidos pelo timbre da voz, relembrando aos espectadores a ausência do marido, através da imagem das partituras, e da filha, pelo som inesperado.
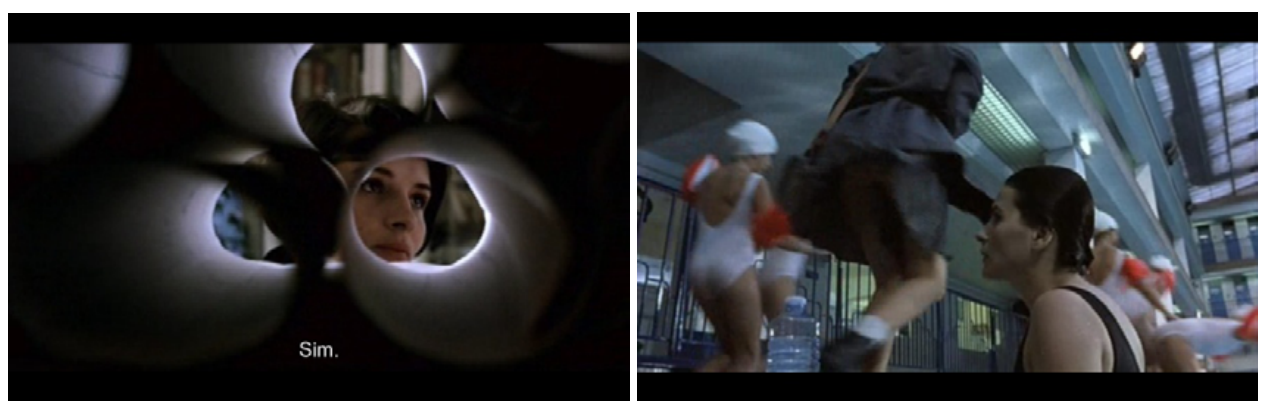

[1] Julie e a copista procuram a partitura do coro da versão de Patrice de "Song for the unification", durante toda sequência ouvimos sons de crianças não-diegéticas;

[2] Enquanto Lucille dirigi-se para a casa de Julie para limpar o cômodo onde os ratos foram mortos, as crianças invadem a piscina interrompendo a sequência.

Técnica amplamente utilizada nas narrativas audiovisuais, o fade out é uma elipse e, como tal, geralmente demarca uma passagem de tempo: a cena termina, ofade out aparece e uma nova cena começa. Em Bleu, os fade outs são construídos em conjunto com a aparição da música, trazendo o espectador de volta ao mesmo momento, indicando que, apesar do tempo passar, ele é curtíssimo e, de alguma maneira, todos permanecem no mesmo lugar, é uma dilatação temporal, simula a nossa própria ação no dia-a-dia de nos pegar pensando em outra coisa, um escape rápido, durante uma conversa: "a ideia de integrar a música à tela preta é justamente para mostrar que, do ponto de vista subjetivo, entre um 'bom dia' e outro, passam-se horas, anos e, contudo, são apenas alguns poucos segundos (CIMENT, 1993: 24). É necessário observar que a cada fade, a inserção musical, apesar de discursar, em sua maioria, sobre a mesma estrutura harmônica e melódica, sofre interrupções em lugares distintos da frase musical do oboé e tem, inclusive, variações importantes de agógica que corroboram para fortalecer o sentido expressivo daquela inserção.

Quando a jornalista visita Julie no hospital, a fim de questioná-la sobre a autoria das músicas do marido, ela diz "bom dia", já estamos ouvindo "Julie glimpses of burial" e vemos a imagem manchar-se em azul. Na pausa da música Julie responde "bom dia" e o primeiro fade out preto do filme se inicia, acompanhado da música e sugerindo que, para Julie, o tempo real rapidamente suspendeu-se. O mesmo acontece quando a vizinha se aproxima dela na piscina na sequência apontada acima. Outro exemplo é quando Antoine, jovem que presenciou o acidente, procura Julie e pergunta: "Você não quer saber nada? Eu cheguei ao carro poucos segundos depois...", ao que é interrompido por um brusco "Não!" e mais um fade out no qual temos uma variação de "Julie..." chamada "Ellipsis 2", um tutti instrumental seguido do oboé solo que toca em tempo livre, com maior duração 
em suas notas, mas para sem completar o discurso musical, sendo interrompido em sua suspensão, enfatizando a flutuação de Julie sobre a resposta. Finalizado o blackout, prontamente Julie pede desculpas pela sua enfática negativa.

O que Antoine provoca, de fato, em sua breve aparição no encontro com Julie, é a lembrança do acidente, até então resguardado. Ao tentar devolver a corrente de ouro que Julie havia perdido - objeto emblemático, que sugere ligação ele lembra das últimas palavras de Patrice e a induz a falar sobre o marido e de como ele gostava de repetir o final das piadas que contava. Neste mesmo momento, próximo aos dois, acontece a aparição de manifestantes empunhando cartazes, em forma de protesto ou reivindicação. A alusão, aí, constrói-se em duas perspectivas: política, já que certamente aponta para uma unificação europeia que não se dará sem conflitos, questionamentos e protestos, ou até mesmo que essa unificação, baseada quase que exclusivamente em reciprocidade econômica, é frágil, ou até mesmo risível, ao nível da piada. Do ponto de vista da personagem, demonstra sua perturbação interior, já que ela percebe o quanto seu passado lhe parece mais próximo, mais presente. E Antoine, personagem que a princípio pode parecer pequeno e sem muita importância, mostra-se fundamental no filme, já que está presente em duas importantes antecipações na narrativa: a do acidente, que causa o trauma e negação do passado por Julie e nesse encontro, que mostra à personagem a importância de lidar com sua memória.

Além de Antoine, outro personagem, também relacionado às lembranças de Julie, é o flautista de rua, que ela vê pela primeira vez quando está no restaurante próximo à sua casa e imagina que a música tocada por ele é a mesma que ela ouve a todo momento. Frisamos que ela imagina porque, além de estarem espacialmente separados, pois o flautista está do lado de fora do restaurante, a música vai assumindo o primeiro plano sonoro e temos a suspensão total do som ambiente, ficando a flauta imersa em uma reverberação não condizente com a qualidade acústica do espaço que vemos, seu reverb desloca a percepção para o campo da imaginação. A saber, toda vez que a música relativa ao flautista

${ }^{3}$ Não fica claro, em nenhum momento da narrativa, se Julie escreve ou corrige as partituras assinadas por Patrice, mesmo após o questionamento da jornalista. De fato, como afirma o próprio Kieślowski, "não importa se ela é autora ou co-autora, se ela corrige ou cria. Mesmo se ela apenas realizasse as correções ela permaneceria sendo autora ou co-autora porque o foi corrigido se torna melhor do que o que fora produzido antes" (STOK, 1994: 224; tradução nossa).

${ }^{4} \mathrm{Em}$ uma escuta mais aprofundada é possível perceber que a música associada à escrita de Olivier não apresenta dinâmica, agógica, nenhum elemento que possibilite uma sensibilização, é dura e desajeitada, como ele mesmo aponta. Olivier nunca solfeja as partituras, não tem escuta interna, apenas as toca, mesmo no momento da re-orquestração, é a escuta interna de Julie que nos é dada. Outro ponto importante a ser observado é que só ouvimos durante o filme a chamada "Song for the unification", é apenas nessa canção que Julie concentra seus esforços, não no concerto como um todo. aparece ela está imersa nesse espaço sonoro reverberante. Aqui, Kieślowski opta mais uma vez pela ambiguidade e pela coincidência através da figura do músico de rua, que quando inquirido por Julie posteriormente sobre o conhecimento da melodia tocada, responde: "eu invento muitas coisas. Gosto muito de tocar". Em sequência anterior, ao voltar do supermercado, Julie vê o flautista em sua calçada habitual, em frente ao restaurante, mas dessa vez deitado no chão, com a caixa da flauta próxima a ele. Ela se aproxima e pergunta se ele está bem, ele, por sua vez, levanta a cabeça e sorri, enquanto ela empurra a caixa para debaixo da cabeça dele, como uma espécie de travesseiro, enquanto ele sussurra: "é preciso agarrarse a alguma coisa", aos exatos 45 minutos, ou metade do filme.

A partir daí, há uma mudança na narrativa, em especial na postura da personagem, que passa a lidar com os traumas de seu passado, traduzidos pelo enfretamento dos ratos em seu apartamento, pelos vínculos que passa a construir - com sua vizinha, Lucille, com Olivier e até mesmo com Sandrine, a amante de seu marido que está grávida e a quem doa sua antiga casa - e pela iniciativa de voltar a escrever ${ }^{3}$ a música na companhia de Olivier, re-orquestrando a versão já modificada por ele ${ }^{4}$ da música de Patrice, atos que demonstram seu desejo em lidar com as lembranças do marido.

"Não quero bens, presentes, amigos, amor e vínculos. Tudo isso são armadilhas", já afirmou a personagem (TRILOGIA..., Cap. 7). Ao almejar o sentimento de liberdade ligado a não manutenção de vínculos, Julie cai em sua própria armadilha, já que o lustre azul, único objeto que decide manter, perpetua a memória que ela não deseja, mas que coexiste e se faz presente no agora. É essa junção, esse limiar entre duas dimensões distintas de tempo que Kieślowski propõe em Bleu, através da construção de uma ideia de passado não cronológico, onde o agora e o que foi flutuam simultaneamente. Na sequência final, em que Julie e Olivier 
${ }^{5}$ Do latim memento "lembra-te", entre outras acepções temos: "cântico baseado em texto de liturgia fúnebre" ou "pequeno livro ou texto que resume as partes essenciais de um assunto".

(AULETE, 2014)

${ }^{6} \mathrm{~A}$ versão usada na película difere da versão associada a Julie no disco pela ausência do trecho que adentra aos créditos.

${ }^{7}$ É o único momento em que um instrumento de sopro do naipe das madeiras, ou seja, a flauta, é utilizado na orquestração da música, que desde o começo contém apenas instrumentos de metais. Aqui, redemos agradecimentos à percepção de Deyvid Willian Martins. estão abraçados, eles aparecem numa espécie de aquário, aprisionados por uma parede de vidro que a sufoca. A sequência inicia-se com um borrão na tela, numa cena muito similar à que Julie, no início do filme, está hospitalizada e Olivier lhe entrega a tv portátil. Agora, a expressão dela ainda demonstra sua introversão, ao mesmo tempo em que se ouve o coro final de forma integral, assim como Patrice havia previsto para o final de seu concerto inacabado, um memento ${ }^{5}$, sob o texto de 1 Coríntios, capítulo 13 , em grego, porém na versão de Julie ${ }^{6}$. A música nos leva, enquanto percorremos em imagens todos os personagens, até ao final dos créditos, onde ouvimos claramente a flauta incorporada à Canção, instrumento associado à lembrança da figura do músico de rua7, aquele que, como mencionamos, inicia o processo de renascimento para a vida. Metáforas da memória, as paredes em que Julie e Olivier se espremem no ato sexual também estão ligadas à ideia de tempo. O passado, que só existe nele, aprisiona e mostra sua força, de onde é impossível desvencilhar-se.

\section{Referências Bibliográficas}

100 Questões a Krzysztof Kieślowski (1989). Extras do DVD Decálogo, Versátil Home Vídeo, 2009.

BERGSON, Henri. Matéria e memória. São Paulo: Martins Fontes, 1990.

CHION, Michel. A audiovisão: som e imagem no cinema. Lisboa: Texto e grafia, 2009 La música en el cine. Barcelona: Paidós, 1997.

CIMENT, Michel. 'La liberté est impossible'. Positif, no 391, 1993.

Dicionário Aulete online. Disponível em <http://aulete.uol.com.br/memento>. Acesso em 24 mar 2014.

FRANÇA, Andréa. Cinema em azul, branco e vermelho: a trilogia de Kieślowski. Rio de Janeiro: Sette Letras, 1996.

KANDINSKY, Wassily. Do espiritual na arte. São Paulo: Martins Fonte, 1990.

KICKASOLA, Joseph G. "Kieślowski's musique concrète". In: WIERZBICKI, James (org.), 2012. Music, sound and filmmakers: sonic style in cinema. New York: Routledge.

RODRÍGUEZ, Ángel. A dimensão sonora da linguagem audiovisual. São Paulo: Senac, 2006.

STOK, Danusia. Kieślowski on Kieślowski. Cambridge: Faber and Faber UK, 1994.

Bleu: Bande originale du film (CD).Virgin Records Us, 1993.

\section{Filmografia}

Trilogia das Cores: edição definitiva (DVD). Versátil Home Vídeo, 2013.

Direção: Krzysztof Kieślowski

Roteiro: Krzysztof Kieślowski e Krzysztof Piesiewicz

Produção: Marin Karmitz

Música: Zbigniew Preisner

Fotografia: Slavomir Idziak

Edição: Jacques Witta 